\title{
O CASO TALITA: ASPECTOS FACTUAIS, CRIMINOLÓGICOS E JURÍDICOS
}

\author{
Orientação: Prof. Fernando Shimidt de Paula \\ Bruna Gabrielle Tavares, Gleyce Kelly Gomes Santos, \\ Simone Nunes de Miranda e Victoria Elisa de Souza Gomes*
}

\section{RESUMO}

Este artigo procurou analisar os aspectos factuais, criminológicos e jurídicos do crime de homicídio conhecido por Caso Talita, perpetrado por um casal contra o amante da consorte, seguido por ocultação de cadáver. A análise foi realizada pelo Grupo de Estudos de Direito Penal da Universidade Metodista de São Paulo e contou com a presença e colaboração de profissionais da área jurídica.

Palavras-chave: Grupo de estudos. Homicídio. Teses da Acusação. Teses da Defesa.

THE TALITA CASE: FACTUAL, CRIMINOLOGICAL AND LEGAL ASPECTS.

\section{ABSTRACT}

This article sought to analyze the factual, criminological and legal aspects of the crime of homicide known as the Talita Case, perpetrated by a couple against the lover of the consort, followed by concealment of the corpse. The analysis was carried out by the Criminal Law Study Group of the Methodist University of São Paulo and counted on the presence and collaboration of legal professionals.

Keywords: Study group. Homicide. Prosecution theses. Defense theses.

\section{INTRODUÇÃO}

O Grupo de Estudos de Direito Penal da Universidade Metodista de São Paulo existe desde 2013, com 4 reuniões por semestre, sob a supervisão e coordenação direta do Professor Fernando Shimidt de Paula, coautor deste artigo e que congrega voluntariamente alunos de qualquer dos módulos do Curso de Direito da Universidade, contando, na maioria das vezes, com a participação de convidados externos, profissionais do Direito, da Medicina Legal, da Criminalística e do Jornalismo, os quais contribuem sobremaneira com os objetivos e os bons resultados

\footnotetext{
* Alunas da UMESP
} 
alcançados. O Grupo de Estudos visa debater fora das salas de aula assuntos da atualidade, com repercussão jurídico-penal, proporcionando aos alunos aprendizado prático e um olhar crítico sobre o mundo naturalístico.

Embora programadas reuniões presenciais, devido à suspensão das atividades acadêmicas por força do Decreto Estadual n 64.881 de 22/3/2020, que declarou quarentena devido à pandemia da COVID-19, as três últimas reuniões aconteceram em ambiente virtual, na plataforma Collaborate, colocada à disposição pela Universidade Metodista de São Paulo. As reuniões contaram com a presença dos 60 alunos inscritos, ex-alunos, do juiz federal aposentado dr. Gilson Idelfonso de Oliveira e da promotora de justiça dra. Thelma Thais Cavarzere, do Tribunal do Júri da Comarca de São Bernardo do Campo, os quais abrilhantaram os debates e marcaram indelevelmente a importância dos trabalhos realizados.

A dinâmica consistiu em apresentar os fatos sob o enfoque criminológico, debatendo-se as suas causas e consequências no meio social, bem como sob o enfoque jurídico, expondo-se o olhar da investigação, do Ministério Público, da defesa técnica e do Poder Judiciário. Para tanto, o professor coordenador contou com a valiosa participação das alunas Bruna Gabrielle Tavares, Simone Nunes de Miranda, Gleyce Kelly Gomes Santos e Victoria Elisa de Souza Gomes, para as quais foram destinadas tarefas específicas. Elas puderam apresentar, diretamente, seus pontos de vista, cada uma trazendo para si o protagonismo do jornalista, do promotor de justiça, do advogado de defesa e do juiz de direito.

Nesse sentido, as quatro alunas foram estimuladas a se debruçar sobre um caso real de homicídio, mas com olhares diferenciados, cada qual trouxe suas impressões, elogios e críticas sobre o fato em si e o desempenho dos profissionais envolvidos.

\section{HOMICÍDIO}

\subsection{CONCEITO}

Matar alguém: Pena, reclusão de seis a vinte anos, ecoa de forma simples e direta o art. 121 do Código Penal.

Nelson Hungria, o maior penalista da história brasileira, em seus comentários ao Código Penal de 1940, traz a definição do conceito da palavra homicídio partindo da análise de inúmeros juristas que o precederam, mas, para ele a definição mais clara e preferível é a do jurista italiano Giovanni CARMIGNANI (1768 -1847): o "homicídio (de hominis excidium) é a violenta hominis caedes ab homine injuste patrata (ocisão violenta de um homem injustamente praticada por outro homem). (HUNGRIA, p. 27).

Esse cruel delito acompanha a humanidade desde os mais remotos agrupamentos humanos e no dizer de Hungria "nos tempos bíblicos era punido com a pena de morte" (HUNGRIA, p. 10), sendo o tipo central dos crimes contra a vida [...], "é o crime por excelência", diz o nosso jurista (Hungria, p. 25).

Além dessa definição clássica de Hungria de que o homicídio é o crime por excelência, encontramos no Vocabulário Jurídico de De Plácido e Silva a seguinte definição para homicídio: 
Do latim homicidium (morte violenta), é geralmente entendido como toda ação que possa causar a morte de um homem (ser humano). Assim, no sentido penal, homicídio exprime a destruição da vida de um ente humano, provocada por ato voluntario (ação ou omissão) de um outro homem ou ser humano. São, pois, elementares, para a constituição do homicídio, como delito: a) a preexistência de uma vida humana; b) o ato voluntário do agente, causa eficiente da morte ou destruição provocada, seja esta consequente de ação ou omissão; c) a intenção determinada no agente para produzir a destruição, isto é, o animus necandi. Segundo as circunstâncias em que o homicídio se pratica é ele dito de: simples, qualificado, culposo e doloso. [...] (DE PLACIDO E SILVA p. 692).

Homicídio casual, consumado, culposo, doloso, involuntário, necessário, piedoso, preterintencional, qualificado, simples, tentado, são terminologias ligadas ao conceito de homicídio e que identificam o tipo penal a que se refere.

\subsection{OBJETIVIDADE JURÍDICA}

Temos então que qualquer pessoa, independentemente de cor e classe social, pode ser sujeito ativo ou passivo do crime de homicídio. Ouçamos o que Hungria tem a dizer sobre o sujeito passivo do homicídio:

É suficiente a vida; não importa o grau da capacidade de viver. Igualmente não importam, para a existência do homicídio, o sexo, a raça, a nacionalidade, a casta, a condição ou valor social da vítima. Varão ou mulher, ariano ou judeu, parisiense ou zulu, brâmane ou pária, santo ou bandido, homem de gênio ou idiota, todos representam vidas humanas. O próprio monstro (abandonada a antiga distinção entre ostentum e monstrum) tem sua existência protegida pela lei penal. (HUNGRIA, p.37).

Para ele não deve existir distinção de pessoas, a vida da pessoa humana é o bem jurídico a ser tutelado pelo Direito Penal. (HUNGRIA, p. 37). Todas as vidas humanas importam.

Procuramos uma definição para a palavra "pessoa" nos dicionários de filosofia, teologia e sociologia e nos deparamos com uma vasta discussão sobre o termo. Não cabe aqui discutirmos a gênese da palavra, pois o espaço não permite, queremos apenas ressaltar que:

A pessoa é uma noção simultaneamente jurídica e moral. Designa o homem (ser humano) enquanto sujeito consciente e racional, capaz de distinguir o bem e o mal, o verdadeiro e o falso, e podendo responder pelos seus atos ou pelas suas opções. A ideia de pessoa é-nos hoje familiar. O respeito e a dignidade da pessoa são universalmente admitidos e constantemente reafirmados, ao nível de princípios. Portanto, a ideia de pessoa é complexa, tal como testemunham os debates éticos contemporâneos. Elaborou-se, progressivamente, a partir de diversas fontes históricas; simultaneamente religiosas, jurídicas e filosóficas. (DICIONÁRIO PRÁTICO DE FILOSOFIA, 1997, p. 297). 
Observe que a definição acima reporta a uma pessoa humana, sujeito de direitos e de deveres como preceitua nosso ordenamento jurídico.

O ser humano é por si só complexo, e sua constituição enquanto ser humano se dá na sua relação com o outro, também ser humano, ser social que é, da mesma forma, sujeito de diretos e deveres numa sociedade multifacetada.

A fragilidade é condição inerente à vida. Toda existência humana é frágil e viver e morrer faz parte da nossa condição existencial. Mas o que queremos enfatizar a partir da afirmação transcrita acima é o fato de que a vida humana precisa de subsídios para que sua existência - desde o nascimento até a morte que, na concepção ideal, deveria acontecer na velhice depois de uma vida longeva e feliz - transcorra de forma natural e que essa precariedade que é comum a todos nós humanos, tenha a proteção da família, da sociedade e do Estado para que ninguém seja vítima de um crime tão cruel quanto é o homicídio.

E é essa particularidade específica do ser humano, um ser jurídico e moralmente constituído, um ser frágil e precário que nos torna aptos a sermos tutelados pelo Direito Penal enquanto participantes de uma determinada coletividade.

Só tem sentido a proteção legal de um bem jurídico que orbite na esfera da coletividade, ensina o grande mestre Hungria (p.10), e a destruição de uma vida humana atinge a família e a sociedade como um todo. Daí a necessidade da proteção jurídica desse bem precioso que, existindo, floresce, mas quando é tirada deixa marcas profundas naqueles e naquelas que compartilhavam suas vidas com a vítima do homicídio.

\subsection{ELEMENTO SUBJETIVO}

A característica específica do homicídio é o animus necandi do agente, ou seja, o dolo, ou a vontade livre e consciente do autor desse crime. Mas há também a modalidade culposa. Ambos descritos no art. 121 do Código Penal. No caput temos a descrição do homicídio simples, sendo a pena para o ato de matar alguém será de seis a vinte anos. O parágrafo primeiro é direcionado para as causas de diminuição de pena, no conhecido homicídio do tipo privilegiado:

Se o agente comete o crime impelido por motivo de relevante valor social ou moral, ou sob o domínio de violenta emoção, logo em seguida a injusta provocação da vítima, o juiz pode reduzir a pena de um sexto a um terço. (CÓDIGO PENAL, art. 121).

Com relação às duas figuras do homicídio privilegiado contidas no parágrafo primeiro, para a primeira: relevante valor social ou moral, Rogerio Greco dá a seguinte definição:

Social: é aquele motivo que atende aos interesses da coletividade. A morte de um traidor da pátria, no exemplo clássico da doutrina, atenderia à coletividade, encaixando-se no conceito de valor social. Moral: é aquele que, embora importante, é considerado levando-se em conta os interesses do agente. Seria, por assim dizer, um motivo egoisticamen- 
te considerado, a exemplo do pai que mata o estuprador de sua filha. (GRECO, p 329).

E em relação à segunda figura do homicídio privilegiado, sob o domínio de violenta emoção, logo em seguida a injusta provocação da vítima, Greco diz:

Emoção, na definição de Hungria, "é um estado de ânimo ou de consciência caracterizado por uma viva excitação do sentimento. É uma forte e transitória perturbação da efetividade, a que estão ligadas certas variações somáticas ou modificações particulares das funções da vida orgânica (pulsar precípite do coração, alterações térmicas, aumento da irrigação cerebral (...) suor, lagrimas etc.)". Logo em seguida denota relação de imediatidade, de proximidade com a provocação injusta a que foi submetida o agente. Isso não significa, contudo, que logo em seguida não permita qualquer espaço de tempo. O que a lei busca evitar, com a utilização dessa expressão, é que o agente que, provocado injustamente, possa ficar "ruminando" sua vingança, sendo, ainda assim, beneficiado com a diminuição da pena. [...]. Injusta provocação diz respeito ao fato de ter a vítima, com seu comportamento, feito eclodir a reação do agente. (GRECO, pp 328-329).

Como se vê, o legislador procurou estabelecer critérios seguros para beneficiar e minorar a pena do agente em alguns casos do crime de homicídio. Vale lembrar ainda que Hungria nos aconselha a substituir a palavra emoção do parágrafo primeiro, por "cólera", "ira", pois essa é a emoção específica que em nós se produz quando assistimos ou sofremos uma injustiça. (HUNGRIA p. 150).

Mas embora nas relações sociais haja casos em que a pena deve ser diminuída, há outras situações nas quais há a necessidade de aumentar a pena. O parágrafo segundo do artigo 121 do Código Penal traz a modalidade do homicídio qualificado. São sete as qualificadoras, ou seja, as circunstâncias do tipo penal em questão.

I - mediante paga ou promessa de recompensa, ou por outro motivo torpe; II - por motivo fútil; III - com emprego de veneno, fogo, explosivo, asfixia, tortura ou outro meio insidioso ou cruel, ou de que possa resultar perigo comum; IV - à traição, de emboscada, ou mediante dissimulação ou outro recurso que dificulte ou torne impossível a defesa do ofendido; V - para assegurar a execução, a ocultação, a impunidade ou vantagem de outro crime; VI - contra a mulher por razões da condição de sexo feminino; VII - contra autoridade ou agente descrito nos arts. 142 e 144 da Constituição Federal, integrantes do sistema prisional e da Força Nacional de Segurança Pública, no exercício da função ou em decorrência dela, ou contra seu cônjuge, companheiro ou parente consanguíneo até terceiro grau, em razão dessa condição.

Greco, explica da seguinte forma as cinco primeiras qualificadoras do homicídio:

I- A paga é o valor ou qualquer outra vantagem, tenha ou não natureza patrimonial recebida antecipadamente, para que o agente leve adiante a empreitada criminosa. Quanto à promessa de pagamento, o agente não recebe antecipadamente, mas existe uma promessa de pagamento 
futuro. [...]. Motivo torpe é o motivo abjeto que causa repugnância, nojo, sensação de repulsa pelo fato praticado pelo agente. [...] II - Motivo fútil, segundo Heleno Fragoso, "é aquele que se apresenta, como antecedente psicológico, desproporcionado com a gravidade da reação homicida, tendo-se em vista a sensibilidade moral média". [...]. III - Emprego de veneno, fogo, explosivo, asfixia, tortura ou outro meio insidioso ou cruel, ou de que possa resultar perigo comum. Veneno. Que deve ser ministrado insidiosamente sem que a vítima tenha conhecimento, é, de acordo com a lições de Almeida Junior, Taylor e Fonzes Diacon: a) toda substância que, atuando química ou bioquimicamente sobre o organismo, lesa a integridade corporal ou a saúde do indivíduo ou que lhe produz a morte; [...]. O fogo também qualifica o homicídio, uma vez que trata de meio extremamente cruel à sua execução. [...]. Explosivo [...] segundo Hungria, "na sua decomposição brusca, o explosivo opera a violenta deslocação e destruição de matérias circunjacentes", trazendo perigo, além de matar a vítima, a um número indeterminado de pessoas. [...]. Asfixia: é a supressão da respiração e segundo Hungria "o texto legal não distingue asfixia mecânica de asfixia tóxica". [...] Tortura, que busca o resultado morte e que difere daquela prevista na Lei $n^{\circ} 9.455 / 1997$. [...] Insidioso é o meio que o agente utiliza sem que a vítima saiba; Cruel, a seu turno é aquele que causa um sofrimento excessivo, desnecessário à vítima enquanto viva. [..] IV - À traição, de emboscada, ou mediante dissimulação ou outro recurso que dificulte ou torne impossível a defesa do ofendido Segundo lições de Guilherme de Souza "[...] é a ação do agente que colhe a vítima por trás, desprevenida, sem ter esta qualquer visualização do ataque". [...] A emboscada [..] o agente se coloca de tocaia, aguardando a vítima passar, para que o ataque tenha sucesso... [...] V - Para assegurar a execução, a ocultação, a impunidade ou vantagem de outro crime. Toda vez que for aplicada a qualificadora do inciso $\mathrm{V}$, o homicídio deverá ter relação com outro crime, havendo outrossim, a chamada conexão. (GRECO, pp 331-333).

Observamos então que o legislador, ao proteger o nosso bem jurídico maior que é a vida, estipulou hipóteses em que a pena deve ser aumentada, pois cada crime merece ser punido dentro dos parâmetros legais, para que a vítima tenha sua honra e dignidade humana preservada, diante da correta penalização do autor do crime.

A respeito das qualificadoras dos incisos VI e VII, foram introduzidas pelas Leis $\mathrm{n}^{\circ} \mathrm{s} 13.104$ e 13.142, ambas de 2015.

No que diz respeito à qualificadora do inciso VI, o sujeito ativo pode ser qualquer pessoa como no homicídio comum, mas o sujeito passivo precisa ser mulher na sua condição do sexo feminino, ou seja, não basta ser mulher, tem que haver a condicionante do menosprezo à condição de ser mulher.

A chamada Lei do Feminicídio foi aprovada pelo parlamento brasileiro após intenso estudo sobre a violência contra a mulher, produzido pela Comissão Parlamentar Mista de Inquérito sobre a Violência contra a Mulher, que investigou e apurou os casos ocorridos no Brasil entre o mês de março de 2012 e o mês de julho 2013. (CNJ). 
Essa lei só foi aprovada após muita pressão popular, haja vista que dados de 2015 mostram que o Brasil é o $5^{\circ}$ no ranking mundial da violência contra a mulher:

O Brasil só perde para El Salvador, Colômbia, Guatemala e Federação Russa em número de casos de assassinato de mulheres. Por aqui, muitos desses casos ocorrem em municípios de pequeno porte, onde não há delegacias da mulher. Na ausência de uma delegacia especializada, as vítimas de violência recorrem às delegacias tradicionais, onde há menos preparo dos policiais para lidar com casos desse tipo. (CONSELHO NACIONAL DE JUSTIÇA).

Essa conquista da sociedade brasileira, especialmente das mulheres após décadas e mais décadas de luta em prol dos direitos básicos de cidadania e da dignidade humana, é fruto também da luta de uma mulher: Maria da Penha.

A Lei n. 11.340, sancionada em 7 de agosto de 2006, passou a ser chamada Lei Maria da Penha em homenagem à mulher cujo marido tentou matá-la duas vezes e que desde então se dedica à causa do combate à violência contra as mulheres (CNJ).

Dentro dessa qualificadora há ainda os casos de aumento de pena que são:

A pena deve ser aumentada de um terço até a metade se o crime for praticado durante a gestação ou nos três meses posteriores ao parto. $\mathrm{O}$ aumento da penalidade incidirá ainda se for cometido contra menor de 14 anos de idade, maior de 60 anos de idade, portadoras de deficiência ou na presença física ou virtual de descendente ou ascendente da vítima. (Código Penal, art. 121, § $7^{\circ}$ )

Nos casos de aumento de pena, fica evidente que o legislador se sensibilizou que, nesses casos, há uma maior vulnerabilidade da mulher gestante, ou à que deu à luz recentemente, bem como à fragilidade física e psicológica da adolescente, da criança e das mulheres acima de 60 anos.

E em relação à qualificadora prevista no inciso VII, é preciso que o homicídio tenha sido praticado enquanto algumas das autoridades ou agentes mencionados nesse inciso estiverem no exercício da função ou em decorrência dela, assim como a morte de um cônjuge ou um parente consanguíneo até terceiro grau, precisa estar motivada diretamente em razão dessa condição especificada na qualificadora.

É comum ouvirmos no noticiário sobre crimes, que ocorrem no Brasil e no mundo, duplamente ou triplamente qualificados. O que diferencia um tipo do outro é a circunstância elementar do fato.

Há ainda, segundo o Código Penal, crimes que podem ser praticados por um só agente ou em concurso de agentes.

E nesse caso, nos reportamos ao art. 29 do Código Penal. 


\title{
1.4 CONCURSO DE PESSOAS
}

O Título IV do Código Penal, no art. 29, trata do Concurso de pessoas.

\begin{abstract}
Art. 29 - Quem, de qualquer modo, concorre para o crime incide nas penas a este cominadas, na medida de sua culpabilidade;

$\S 1^{0}$ - Se a participação for de menor importância, a pena pode ser diminuída de um sexto a um terço.

$\S 2^{\circ}$ - Se algum dos concorrentes quis participar de crime menos grave, ser-lhe-á aplicada a pena deste; essa pena será aumentada até metade, na hipótese de ter sido previsível o resultado mais grave.
\end{abstract}

A regra inserta no art. 29 exprime a possibilidade de responsabilização de duas ou mais pessoas que colaborarem para a prática de um crime ou contravenção penal. Essa mutualidade pode ser demonstrada tanto nos casos em que são vários os autores como naqueles casos em que existirem autores e participantes, ensina Greco.

Os requisitos para que o concurso de pessoas seja validado são: pluralidade de autores e de conduta; relevância causal de cada conduta; liame subjetivo entre os agentes e identidade de infração penal. (GRECO, p.110).

Existem três teorias jurídicas sobre o crime em concurso de pessoas, são elas: a Teoria Pluralista da Ação; a Teoria Dualista da Ação e a Teoria Monista da Ação.

Na Teoria Pluralista, existirão tantos crimes ou infrações penais quantos forem seus atores e partícipes, enquanto na Dualista há distinção entre os crimes ou infrações penais cometidas pelos autores daqueles praticados pelos partícipes, sendo a pena dos autores distinta da dos partícipes.

Já a Teoria Monista da Ação ou Unitária, que é a adotada pelo ordenamento jurídico brasileiro, alude que todos aqueles que colaboram para a execução do crime são afetados nas penas a este imposta, na medida de sua culpabilidade, ou seja, na medida de sua participação, sendo por ação ou omissão. Nesta teoria, há um único crime. Indivisível, portanto.

Por força constitucional, os crimes dolosos contra a vida são julgados pelo Tribunal do Júri, como veremos a seguir.

\section{TRIBUNAL DO JÚRI}

\subsection{FundamentaÇÃo LEGAL}

O Tribunal do Júri é uma instituição constitucional estabelecida como direito individual no inciso XXXVIII da Constituição Federal, contribui para a democracia e insere na sociedade uma forma diferente de julgar alguns crimes. $\mathrm{O}$ referido artigo foi promulgado pela Constituição Federal de 1988 e dispõe:

Art. $5^{\circ}$, XXXVIII, CF - é reconhecida a instituição do júri, com a organização que lhe der a lei, assegurados:

a) a plenitude de defesa; 

b) o sigilo das votações;
c) a soberania dos veredictos;
d) a competência para o julgamento dos crimes dolosos contra a vida.

Segundo o doutrinador Alexandre de Moraes, a instituição do Júri tem origem anglo-saxônica e é uma prerrogativa democrática do cidadão, para a pessoa acusada da prática de certos crimes graves e que por isso será julgada pela própria sociedade. (MORAES, 2017, p. 76).

O Júri também recebe o nome de Tribunal Popular, tem obrigação constitucional e é composto por um juiz presidente e 25 Jurados, dos quais serão sorteados e escolhidos apenas sete para constituírem o Conselho de Sentença.

A criação do Tribunal do Júri é tão obscura que Carlos Maximiliano, depois de muita pesquisa, afirma que "(...) as origens do instituto, são tão vagas e indefinidas, que se perdem na noite dos tempos". (1948, p. 156 apud TUCCI, 1999, p. 12).

De qualquer forma, tem-se que o Tribunal do Júri teve origem na Grécia Antiga, em Roma, na Inglaterra e na França em momentos distintos e cada qual do seu modo, porquanto as instituições de então em muito se assemelham ao que temos hoje. No Brasil, o Tribunal do Júri existe no ordenamento jurídico desde 1822, sofrendo ao longo do tempo diversas alterações até chegar ao modelo dos dias atuais.

A importância do Tribunal do Júri reflete a própria importância da democracia, pois todo poder emana do povo e em seu nome é exercido e, por meio dessa instituição, o povo conhece e julga seus pares por crimes graves. No modelo brasileiro, a teor do disposto na Constituição de 1988, são da sua competência os crimes dolosos contra a vida humana, certamente o bem jurídico mais importante do nosso ordenamento jurídico.

O Tribunal do Júri se fundamenta na Constituição Federal de 1988 (art. 5, inciso XXXVIII), no Código Penal que tipifica os crimes dolosos contra a vida nos arts. 121 a 128 e aqueles que lhe são conexões (arts. 76, 77 e 78, I) e, por fim, no Código de Processo Penal (arts. 74, 106, 394, §3ㅇ, 406 a 497, 593, III, 598, 668 e 699).

Para falarmos um pouco sobre o procedimento do Tribunal do Júri devemos observar a Lei $\mathrm{n}^{\circ} 11.689 / 08$, que modificou alguns ritos, como, por exemplo, a ordem de inquirições e a idade para funcionar como jurado.

De acordo com o art. 406 do Código de Processo Penal, o julgamento pelo Tribunal do Júri deve obedecer ao rito especial, bifásico ou escalonado, possuindo assim duas fases.

A primeira fase, conhecida como "sumário da culpa", tem início perante a decisão de recebimento da denúncia pelo juiz competente e se encerra com a preclusão da decisão de pronúncia (momento em que o réu, perante o juiz togado, é submetido ao julgamento de admissibilidade pelo Tribunal do Júri). Essa decisão, como todas as outras, deve ser fundamentada e, a priori, prevalece o princípio do in dubio pro societate. Contra essa decisão cabe o Recurso em Sentido Estrito (CPP, art. 581, IV), além de habeas corpus.

A segunda fase, conhecida como "juízo da causa", abrange a intimação das partes para arrolarem testemunhas (que irão depor em plenário), a instauração 
da sessão do júri, a oitiva dessas testemunhas, o depoimento pessoal do acusado e os debates orais, culminando na votação que os jurados farão em sala secreta e na leitura do veredito pelo juiz presidente, que, por sua vez, prolatará a sentença.

De acordo com o art. 447 do Código de Processo Penal, o Tribunal do Júri é composto por um juiz presidente e 25 jurados, os quais serão submetidos a sorteio e apenas sete farão parte do Conselho de Sentença que, ao final, decidirá se o réu é culpado ou não.

\section{CASO TALITA}

Nos autos do processo $n^{\circ}$ 0005959-16.2017.8.26.0564, da Vara do Júri de São Bernardo do Campo, em 17/3/2017 foi oferecida denúncia contra Anderson Pereira de Souza por violação aos arts. $121 \S 2^{\circ}$, incs. I e III, 211, c/c o art. 69 do Código Penal e contra Talita Neves Pereira Barrence de Souza por infração ao art. 211 do mesmo codex (fl. 85 a 89). No entanto, no dia 31 do mesmo mês, após o irmão da vítima ser ouvido, a denúncia foi aditada, imputando-se aos réus as mesmas infrações: art. 121, $\S 2^{\circ}$, incs. I, III e IV e art. 211, c/c o art. 69 do Código Penal (fl. 104 a 109).

Em 09/11/ 2017 (fl. 391 a 410), Talita foi pronunciada somente pelo crime de ocultação de cadáver enquanto Anderson, por homicídio qualificado pelo motivo torpe e recurso que tornou impossível a defesa da vítima, bem como ocultação de cadáver, portanto afastada a qualificadora do meio cruel.

O Ministério Público e os réus Talita e Anderson recorreram da sentença, porém só o Ministério Público teve seu recurso provido.

O julgamento do casal estava marcado para o dia 12/02/2020, mas devido às chuvas que caíram sobre a cidade de São Paulo e região metropolitana naquela semana, o réu Anderson (preso no Centro de Detenção Provisória de Pinheiros) não foi apresentado e somente Talita foi julgada, sendo condenada às penas de 15 anos, 04 meses e 24 dias de reclusão e ao pagamento de 10 dias-multa (fl. 883), mas, por força constitucional, teve o direito de recorrer em liberdade. Assim o fez, tendo apelado em 17/02/2020, alegando:

1. Ilegalidade pelo desmembramento do processo, devido à impossibilidade de apresentação do réu Anderson, aduzindo que o julgamento poderia ser outro;

2. Não haver prova nos autos da participação da ré Talita no homicídio e que o auxílio na ocultação do cadáver se deu mediante coação moral irresistível e, por isso, pleiteia novo julgamento pelo Tribunal do Júri. $\mathrm{O}$ Ministério Público apresentou contrarrazões de apelação em 21/2/2020, tendo o recurso subido ao Tribunal de Justiça, onde a Procuradoria Geral de Justiça se manifestou em 21/5/2020 pelo improvimento do recurso. Até o momento em que escrevemos esse artigo nem Anderson e nem o recurso de Talita foram julgados. 


\subsection{GENERALIDADES}

3.2 Pudemos perceber que os protagonistas residiam próximos uns dos outros:

1. Casa da vítima: Rua Alberto Benecasa, 154 Montanhão, SBC.

2. Casa da Talita: Rua do Oleoduto, 108, Vila São Pedro, SBC.

3. Casa do Anderson: Rua Alto da Bela Vista, 405, Montanhão, SBC

4. Local do encontro da moto da vítima: Rua Paraná, 129, Vila São Pedro, SBC.

5. Local do encontro do cadáver: Rua Giacinto Tognato, 2740, Baeta Neves, SBC.

6. Local dos fatos: Rua do Oleoduto, 108, Vila São Pedro, SBC.

7. Motel: Riacho Grande (Via Anchieta, km 28).

Percebemos que o crime perdurou por um período de 11 dias, tendo início no dia 03/3/2017 e seu desfecho com o encontro do cadáver e prisão dos autores no dia 13/3/2017.

Abaixo segue tabela com algumas particularidades dos protagonistas, como idade, profissão, escolaridade, altura e cor da pele:

\begin{tabular}{|l|l|l|l|l|l|}
\hline Nome & Idade & Profissão & Escolaridade & Altura & Cor \\
\hline Anderson & 27 & Motorista & $2^{\circ}$ grau & $1,70 \mathrm{~m}$ & Branca \\
\hline Talita & 28 & Operadora Caixa & $2^{\circ}$ grau & $1,60 \mathrm{~m}$ & Branca \\
\hline Vítima & 28 & Auxiliar Logística & $2^{\circ}$ grau & $1,80 \mathrm{~m}$ & Branca \\
\hline
\end{tabular}

Percebemos que se trata de jovens com instrução mediana, incluídos no mercado de trabalho e com baixa remuneração, moradores da periferia da cidade, de cor branca e estatura mediana. Pessoas comuns, portanto.

Embora não possamos afirmar devido à análise perfunctória dos fatos, mas acreditamos estarem presentes fatores sociais da criminogênese, sejam eles econômicos, decorrentes da deficitária distribuição de renda e não econômicos, tais como a desigualdade social, exclusão social e preconceito.

Em meio aos debates do Caso Talita, várias foram as teses debatidas no Grupo de Estudos, a saber:

1. O crime ocorreu no dia $03 / 3 / 2017$ por volta das 20 horas, na residência situada à Rua do Oleoduto, no 108, Vila são Pedro, São Bernardo do campo (SP);

2. O jovem foi vítima do casal Anderson e Talita;

3. Desaparecido desde 03/3/2017, sexta-feira, quando saiu para jogar futebol com amigos;

4. O corpo foi encontrado no dia 13/3/2017, 11 dias depois do crime;

5. Quem matou o jovem foi Anderson Pereira Santos, a facadas; 
6. A motivação do crime seria passional, uma vez que Anderson descobriu que a companheira, Talita Neves Sousa, mantinha caso extraconjugal com a vítima;

7. Um dia após o desaparecimento da vítima (04/3/2017), a família localizou a moto do rapaz;

8. A polícia chegou a Anderson e Talita por intermédio do irmão da vítima, que recebeu uma ligação anônima;

9. Versão do crime na visão de Anderson;

10. Talita foi coautora do crime;

11. Versão do crime na visão do irmão da vítima;

12. Versão do crime na visão de Talita;

13. Versão apresentada por Anderson e Talita;

14. Talita previa o desfecho da noite;

15. O homicídio em si;

16. O motivo do crime;

17. A frieza dos indiciados (eles foram ao cinema e pernoitaram no motel após cometer o crime);

18. Relações conjugais e extraconjugais;

19. Nível econômico e social dos envolvidos;

20. Uso de álcool e drogas;

21. O corpo da vítima foi encontrado mais de uma semana após o crime;

22. Quem ajudou a polícia no desfecho do crime foi o irmão da vítima.

De outra parte, podemos destacar que o crime de homicídio praticado por Talita e seu marido Anderson não está isolado em nossa sociedade, pois, ao contrário, vários outros são praticados e medidos pelas estatísticas oficiais.

\begin{tabular}{|l|l|l|}
\hline Ano & Homicídios & Variação percentual \\
\hline 2015 & 3759 & - \\
\hline 2016 & 3521 & $-6,33 \%$ \\
\hline 2017 & 3294 & $-6,45 \%$ \\
\hline 2018 & 2949 & $-5,69 \%$ \\
\hline 2019 & 2778 & $-5,47 \%$ \\
\hline
\end{tabular}

Fonte: SSP/SP

Em 2019 o estado de São Paulo registrou uma queda de 5,47\% nos casos de homicídio doloso em relação ao ano de 2018, que registrou um índice de 5,69 \% a menos do mesmo caso.

O Estado de São Paulo registrou em março de 2020 o primeiro aumento de casos de homicídio em seis anos, de $23,3 \%$, quando comparados ao mesmo período do ano de 2019, segundo as estatísticas criminais divulgadas pela Secretaria da Segurança Pública (SSP): 


\begin{tabular}{|l|c|c|c|c|r|}
\hline \multicolumn{1}{|c|}{ Natureza } & Jan & Fev & Mar & Abr & Total \\
\hline $\begin{array}{l}\text { Homicídio } \\
\text { no ano de } 2020\end{array}$ & 263 & 210 & 286 & 263 & 1.022 \\
\hline
\end{tabular}

Fonte: SSP/SP

O número de casos de homicídio doloso começou o ano de 2020 em queda: foram registrados 263 casos em janeiro e 210 casos no mês de fevereiro, mas a quantidade de casos aumentou para 286 em março e teve uma queda novamente no mês de abril, com 263 casos registrados, sendo o total de 1.022 de janeiro a abril de 2020 .

O caso estudado no grupo de estudo de Direito Penal ocorreu na cidade de São Bernardo do Campo, na região metropolitana de São Paulo, onde também ocorreu uma queda nos primeiros seis meses do ano de 2019, segundo dados divulgados pela Secretaria de Segurança Pública de São Paulo. Em relação à cidade de São Bernardo do Campo, teve um aumento de 16,7\%, sendo registradas 18 ocorrências no ano de 2018 e 21 ocorrências no ano de 2019.

Podemos concluir que os casos de homicídio no Estado de São Paulo e na cidade de São Bernardo do Campo são mais comuns do que imaginamos. A cada dia que passa assistimos na televisão ou em jornais, casos em que uma pessoa matou a outra por " $\mathrm{n}$ " motivos, sendo eles fúteis, como, por exemplo, brigas de trânsito, brigas domésticas e discussões entre pessoas alcoolizadas e munidas de armas. Oportuno mencionar que a mídia estereotipa os casos de homicídios ocorridos em nosso país, procurando sempre vincular a violência na sociedade às pessoas marginalizadas, negros, pardos ou jovens.

A seguir trataremos a repercussão na mídia do Caso Talita, crime que tanto ressoou em nossa região.

\subsection{REPERCUSSÕES NA MÍDIA}

Hoje em dia, tem-se anunciado uma série de casos de homicídios que tiveram grande repercussão na imprensa e em todos os seus meios de divulgação. Como formadora de opinião, a mídia tem por objetivo fornecer notícias àqueles insaciáveis por informação.

Entretanto, é vastamente discutido o poder de influência da mídia sobre as pessoas e a relação dela com o Poder Judiciário, especialmente quando alguns crimes contra a vida chocam e são amplamente divulgados e assistidos por todo o país.

Nessa etapa do artigo vamos analisar a repercussão do "Caso Talita" na mídia e na sociedade e, primeiramente, devemos saber qual é o conceito de mídia. Segundo o dicionário de português,

mídia é qualquer suporte de difusão de informações, como rádio, televisão, imprensa escrita, livro, computador, videocassete, satélite de comunicações que constitua simultaneamente um meio de expressão e um intermediário capaz de transmitir uma mensagem a um grupo; meios de comunicação, comunicação de massa. (Ministério Público do Ceará). 
O caso que estudamos no Grupo de Estudos foi divulgado em sites e telejornais. O primeiro site que conseguimos encontrar o caso é o de Renato Fontes, com o título "Jovem desaparecido é encontrado morto em São Bernardo" (fonte: Renato Fontes), a reportagem conta como ocorreu o crime:

O corpo do auxiliar de logística André Souza, 28 anos, que estava desaparecido há mais de uma semana, foi encontrado no início da tarde desta segunda-feira (13/03) em um matagal na rua Giacinto Tognato, no Bairro Baeta Neves, em São Bernardo. De acordo com o Setor Homicídios da Polícia civil no município, responsável pelo caso, o desempregado Anderson Pereira Souza, 27 anos, foi quem matou o jovem a facadas. Com os policiais, o autor do crime indicou o local onde estava o corpo. A motivação do crime seria passional, uma vez que Anderson descobriu que a companheira, Talita Neves Sousa, 28 anos, mantinha caso extraconjugal com André.

Um dia após o desaparecimento de André (04/03), a família localizou a moto do rapaz. O veículo estava estacionado e travado. $\mathrm{O}$ capacete da vítima foi encontrado em frente a uma praça na rua Paraná, travessa da rua Oleoduto. Souza era casado e pai de duas filhas, de nove e sete anos. A polícia chegou a Anderson e Talita na manhã desta segunda, após o irmão da vítima ter recebido ligação anônima na madrugada de sexta-feira (10/03) dizendo que André mantinha caso extraconjugal com Talita, que também era casada.

Em depoimento às autoridades, o homem, que confessou o assassinato, contou à polícia que encontrou Talita e André juntos em ato sexual na casa dela, na rua Oleoduto, na Vila São Pedro, também em São Bernardo, na noite do crime. Em momento de fúria, pegou uma faca na cozinha e desferiu vários golpes contra vítima. Depois, com ajuda de Talita, Anderson disse que enrolou com plástico o corpo do auxiliar de logística. Em seguida, foi sozinho até o terreno baldio e ocultou o cadáver em um matagal.

"Foi um momento de raiva. Até agora não sei como tive coragem de cometer uma barbaridade como essa", declarou o assassino. O Setor Homicídios de São Bernardo solicitou à Justiça a prisão preventiva de Anderson e Talita, que foi considerada co-autora por ajudar o marido a ocultar o corpo de André.

\section{RELEMBRE O CASO}

O auxiliar de logística André Souza, 28 anos, tinha sido visto pela última vez, por volta das 17 h da sexta-feira (03/03), quando saiu de casa, no Jardim Regina, em São Bernardo, para jogar bola. Não foi mais visto.

$\mathrm{O}$ último sinal do rastreador do celular foi às $20 \mathrm{~h}$ de sexta, no mesmo local onde estava a moto do auxiliar de logística. O desaparecimento foi registrado no $1^{\circ} \mathrm{DP}$ (Distrito Policial) de São Bernardo.

O caso, também noticiado no programa "Cidade Alerta" em reportagem de Marcelo Rezende, com o título "Mulher retoma o relacionamento com o marido e os dois matam o ex-amante". A reportagem foi ao ar no dia 14/3/2017 (fonte: Record TV), um dia depois de ser encontrado o corpo da vítima. A notícia no site da Record TV faz um resumo do caso: 
André, de 28 anos, saiu de casa para jogar futebol e desapareceu. Seu corpo foi encontrado dias depois, em um matagal em São Bernardo do Campo, no ABC Paulista. Atrás de explicações para o crime, o irmão da vítima descobriu o envolvimento de Talita, uma mulher com quem André tinha um relacionamento. Ela estava separada do marido e começou a sair com André para fazer ciúme no ex. Depois de algum tempo, os dois acabaram se unindo para tirar a vida do amante. $\mathrm{O}$ casal foi preso. (TV RECORD, 2017).

O objetivo desse tópico no presente artigo era fazer uma reflexão acerca da influência da mídia em crimes de grande repercussão no nosso país. A justificativa para a presente pesquisa é a atuação da mídia como formadora de opinião e sua influência na opinião da sociedade e dos jurados. Ainda que a mídia faça parte do dia-a-dia das pessoas, sua influência no processo penal é um tema ainda muito discutido.

\subsection{TESES DE ACUSAÇÃO}

Para melhor elucidação, mostraremos as teses alegadas pelo Ministério Público dividindo-as em duas partes: o oferecimento da denúncia e o seu respectivo aditamento que alterou, significativamente, a posição de Talita nos crimes ora apresentados.

A denúncia foi oferecida no dia 17/3/2017, quando Anderson foi apresentado como único autor do crime de homicídio, incorrendo nas qualificadoras do motivo torpe e meio cruel, devidamente positivadas no art. 121 , $\$ 2^{\circ}$, I e III, do Código Penal.

A promotora responsável por esta análise, entendeu que o motivo torpe foi configurado em virtude do sentimento de vingança percebido em Anderson após encontrar Talita, sua então ex-companheira, em atos sexuais consentidos com a vítima, enquanto o meio cruel em razão de o acusado ter amarrado a vítima pelas mãos e pés, o que impediu a sua defesa diante de golpes de faca que recebia na região do pescoço.

Além desse tipo penal, Anderson também foi denunciado por ocultação de cadáver, com base no art. 211, em concurso material delimitado no art. 69, ambos do Código Penal, caracterizado quando há a prática de mais de um crime, por mais de uma ação, somando-se as respectivas penas. Decisão também demonstrada no v. Acórdão abaixo:

AGRAVO REGIMENTAL NO RECURSO ESPECIAL. ESTUPRO DE VULNERÁVEL. HOMICÍDIO QUALIFICADO. CONCURSO MATERIAL. DOSIMETRIA DA PENA. CIRCUNSTÂNCIAS E CONSEQUÊNCIAS INERENTES AO PRÓPRIO TIPO PENAL DO ART. 217-A DO CÓDIGO PENAL. VALORAÇÃO NEGATIVA.IMPOSSIBLIDADE. 1.Não é dado ao juiz sentenciante se utilizar de circunstancias e consequências inerentes ao tipo violado para elevar a reprimenda imposta ao réu. 2. O fato de o crime ter sido praticado para a satisfação da lascívia contra menor de idade, embora sobejamente graves, são circunstâncias inerentes 
ou comuns aos delitos de estupro de vulnerável. 3. Comoção social e os reflexos nos familiares da ofendida são consequências abstratas e inerentes ao delito, razão pela qual não podem justificar elevação da pena base. 4. Agravo regimental desprovido. (AgRg no REsp 1636954/CE, Rel. Ministro JORGE MUSSI, QUINTA TURMA, julgado em 17/08/2017, DJe 23/08/2017 - grifo nosso).

Talita, por sua vez, foi acusada apenas pelo crime de ocultação de cadáver, na qualidade de partícipe, tendo em vista que acompanhou Anderson até as proximidades de um cemitério da cidade, onde o corpo da vítima foi desovado.

No aditamento da denúncia ocorrido no dia 31 de março do mesmo ano, portanto 14 dias depois do primeiro oferecimento, Talita passou a ser a personagem principal da trama, tomou lugar de destaque como partícipe no crime de homicídio. Isso foi possível após a relevante colaboração do irmão da vítima na investigação dos fatos, demonstrando indícios de envolvimento no homicídio não só de Anderson, mas também de sua companheira Talita.

As alterações na denúncia que implicaram criminalmente a personagem Talita foram realizadas, basicamente, seguindo a conjuntura do dolo eventual, instituto positivado na segunda parte do inciso I do art. 18 do Código Penal, segundo o qual atua com dolo eventual o agente que, mesmo não tendo a intenção direta de conseguir o resultado morte, assume o risco de produzi-lo.

Luiz Regis Prado enaltece a diferença entre dolo eventual e culpa consciente:

No dolo eventual, o agente presta anuência, consente, concorda com o advento do resultado, preferindo arriscar-se a produzi-lo a renunciar à ação. Ao contrário, na culpa consciente, o agente afasta ou repele, embora inconsideradamente, a hipótese de superveniência do evento e empreende a ação na esperança de que este não venha a ocorrer - prevê o resultado como possível, mas não o aceita, nem o consente. (PRADO, 2008, p. 331 - grifo nosso).

No caso a que fazemos referência é importante destacar que, no entendimento da promotoria, Talita incorreu em dolo eventual na medida em que mostrou as mensagens que trocava com a vítima para o seu ex-companheiro Anderson e, sabendo de seu problemático temperamento, previu, antecipadamente, a sua conduta agressiva e a sua respectiva consequência.

Nas palavras da Promotora:

Nas mesmas circunstâncias de tempo e espaço acima mencionadas, TALITA NEVES PEREIRA BARRENCE DE SOUZA, agindo com dolo eventual, ou seja, assumindo o risco de produzir o resultado morte, concorreu para a prática do crime de homicídio triplamente qualificado acima narrado, posto que, sabendo da personalidade ciumenta e agressiva de ANDERSON PEREIRA DE SOUZA, fez com que ele tomasse conhecimento do local e horário nos quais manteria encontro amoroso com a vítima e, assim agindo, providenciou para que ele fosse até o local dos fatos e a surpreendesse na companhia da vítima, criando a situação fática que culminaria com o óbito da vítima." (fls.104/105). 
Além de considerar o dolo eventual para a caracterização de Talita como protagonista da morte da vítima, as qualificadoras anteriormente atribuídas a Anderson a ela também o foram, vale dizer: motivo torpe e meio cruel. Não obstante, o Ministério Público também entendeu presente outra circunstância qualificadora, a prevista no inciso IV do art. 121 do Código Penal e, por isso, no entendimento da acusação, Talita teria que responder por homicídio triplamente qualificado, respeitando a norma:

Art. 121. Matar alguém:

$\S 2^{\circ}$ Se o homicídio é cometido:

I - mediante paga ou promessa de recompensa, ou por outro motivo torpe;

III - Com emprego de veneno, fogo, explosivo, asfixia, tortura ou outro meio insidioso ou cruel, ou de que possa resultar perigo comum;

IV - À traição, de emboscada, ou mediante dissimulação ou outro recurso que dificulte ou torne impossível a defesa do ofendido. (CÓDIGO PENAL, inciso IV do art. 121).

Mantido o crime de ocultação de cadáver em concurso material foi, outrossim, destacado, em conjunto, o concurso de pessoas previsto no art. 29 do Código de Penal. De acordo com o texto da lei: "quem, de qualquer modo, concorre para o crime incide nas penas a este cominadas, na medida de sua culpabilidade".

No que concerne ao concurso de pessoas, devem estar presentes os seguintes requisitos:

1. Presença de dois ou mais agentes;

2. Pluralidade de Condutas;

3. Relevância causal de cada conduta;

4. Vínculo entre os agentes

5. Identidade da infração, ou seja, todos devem responder pelo mesmo tipo penal.

Isto posto, vemos que no caso em tela foram preenchidos todos esses pressupostos, tendo em vista a presença de Talita e Anderson como atuantes diretos no crime, as diversas condutas praticadas por cada personagem e a sua relevância para a morte do indivíduo, o vínculo amoroso entre eles e, por fim, a contribuição de ambos para a mesma tipificação penal.

No aditamento da denúncia, Anderson permaneceu como autor do homicídio em conjunto com as qualificadoras, bem como da ocultação de cadáver, em cúmulo material.

Ademais e em virtude do contexto em que Talita foi inserida, qual seja a de partícipe dos crimes, o Ministério Público também requereu, além do reconhecimento das tipificações penais, a decretação de sua prisão preventiva em atenção especial aos requisitos dessa medida cautelar, previstos nos arts. 282 e 312 do Código de Processo Penal. As alegações da promotoria para esse tema apontaram 
para o surgimento de indícios de autoria a prática de um crime gravíssimo que desencadeou clamor público, razão de se preservar a sociedade ao perigo que ensejaria a liberdade da personagem e, sem embargo, sobrevir extrema necessidade de preservação da prova processual.

As teses da acusação utilizadas em sede de oferecimento de denúncia e respectivo aditamento mereceram dignas apreciações do respeitável Juízo, (sendo necessário, por vezes, manifestá-las novamente em fase recursal e também em memoriais). Deste modo e em conformidade com os estudos que permearam as decisões e as teses de defesa e acusação, debruçamo-nos em possíveis institutos que poderiam ser trabalhados pelo Ministério Público como titular da ação penal pública.

A elucidação das versões dos envolvidos e das testemunhas mostraram evidentes contradições, mas, de um modo geral, igualmente demonstraram que a participação de Talita não se limitou a uma atuação secundária, mas possivelmente de mandante do crime. A primeira evidência sobre essa temática está relacionada ao fato de Anderson, indivíduo de temperamento ciumento e agressivo, não ter sequer lesionado Talita, sua ex-companheira, a qual se relacionava sexualmente com a vítima no momento do flagrante.

Se, mediante uma traição, Anderson não se voltou contra a ex-esposa e somente contra quem com ela se relacionava, por lógico emerge a ideia de que ambos já tinham previamente planejado a cena do crime, muito provavelmente engendrado por Talita, ao divulgar ao seu ex-companheiro (Anderson) mensagens íntimas trocadas com a vítima e, principalmente, a mensagem em que combinaram data e local para o encontro amoroso. Além disso, depois do homicídio, ambos os réus pernoitaram em um motel da região, situação que esboça significativamente a frieza de ambos quanto à gravidade do ato, além de possível aproveitamento do resultado.

Destarte, vemos, nas entrelinhas desse processo, a denominada Teoria do Domínio do Fato tomando contorno. Essa teoria delimita de forma concreta a figura do autor e partícipe, contextualizando o autor mediato como aquele que tem controle final do fato, aquele, portanto, que dá o comando e tem o poder de decisão da ação criminosa. Trata-se de uma teoria com aspectos subjetivos e objetivos para a sua caracterização, que desconsidera se há ou não posição hierárquica entre os envolvidos, bastando a presença de controle final (pressuposto subjetivo) e determinação/domínio sobre a prática do fato (pressuposto objetivo). Logo, ser autor de um crime não está restrito à execução daquilo que tornou possível o resultado, mas também aquele que, utilizando-se de outrem, planejou e decidiu sobre aquela execução. Ou seja, no caso estudado neste artigo, ao que parece Talita utilizou Anderson de instrumento para o seu objetivo, tornando-se autora mediata do resultado morte.

Considerando a transformação de Talita de partícipe para autora mediata do delito, vemos que a alegação de dolo eventual pode ser remodelada para dolo direto, na forma do contido na primeira parte do inciso I do art. 18 do Código Penal, abordado anteriormente. 
Em continuidade, também observamos a possibilidade de se abordar na acusação, impressões sobre a realidade dos envolvidos que manifestamente poderia incorrer sobre a intenção dos delinquentes e a postura da vítima na relação com os autores de sua morte. Objetivamente, estamos nos referindo à desestruturação familiar percebida em toda cadeia dos envolvidos (réus e vítima), tendo em vista a instabilidade dos relacionamentos, envolvimento com traições e mentiras e ausência da família para depoimentos favoráveis à Talita e Anderson.

Outro ponto observado é a possível personalidade doentia presente na principal autora, não só por antecipadamente arquitetar o delito, mas também frente à postura ante o resultado final. A reputação dessa personagem também foi alvo de avaliações, mas poderia ser mais arguida em sede de acusação para demonstrar sua possível falha de caráter e, por consequência, a triste possibilidade de uma vida promíscua, relacionada a programas sexuais, por exemplo.

Todos os pontos apresentados pelo Ministério Público e aqueles semeados em ambiente de estudos foram refutados pela defesa, como veremos a seguir.

\subsection{TESES DA DEFESA}

"É papel da defesa encontrar explicações no inexplicável". (FSP1) "Aquele que é o primeiro a fazer a sua defesa parece ter razão". (Pv. 18.17, a)

Na defesa preliminar de Anderson, feita em 12/4/2017, seus defensores alegaram inocência afirmando que:

Através de embasamento nas oitivas acusatórias na fase inquisitiva, constou na denúncia que no dia 03 de março de 2017 o acusado se desentendeu com a vítima em um laço amoroso onde ambos iniciaram uma luta corporal e acabando o ora acusado Anderson sendo superior na luta e feriu a vítima, sendo que a mesma veio a óbito. Tudo aconteceu por causa de uma mulher a qual o acusado amava e a tinha como sua companheira. (fl. 150/151 dos autos do processo).

A defesa prévia da Talita foi feita 30 dias depois, em 12 de maio, da qual consta:

Conforme consta da denúncia de fls.85/89, a denunciada está sendo acusada de ter ocultado, em 04/03/2017, o cadáver da vítima, morto em 03/03/2017, de cuja autoria do evento morte se atribui a Anderson Pereira de Souza, inclusive assumindo a autoria e apontando onde abandonou o cadáver (fls.39/41).

Em aditamento da denúncia às fls.104/110, alega o MP que a denunciada concorreu para a prática do crime, "agindo com dolo eventual, ou seja, assumindo o risco de produzir o resultado morte". Com isto, a denunciada passaria a responder pelas mesmas imputações ao acusado Anderson, ou seja, além da ocultação do cadáver (art.211 CP), também

1 Fernando Shimidt de Paula 
pelo homicídio qualificado (art.121, §2 ${ }^{\circ}$ incisos I, III e IV, do CP).

Ademais, consta dos autos que a denunciada é casada com o acusado Anderson, embora separada de fato, mas que ainda mantinham relacionamento amoroso; que por sua vez, também, a acusada tinha um relacionamento amoroso com a vítima André.

Os acusados e a vítima se conheceram quando trabalhavam no D’ Ávó Supermercados.

No dia dos fatos a denunciada havia marcado um encontro em sua casa, porém, o acusado Anderson chegou depois e, por não se conter pela crise de ciúmes, o teria provocado lesões na vítima, vindo a falecer. $\mathrm{O}$ acusado Anderson providenciou a ocultação do cadáver da vítima, que teve a ajuda da acusada, a pedido.

Alegação de incompetência de juízo: Ainda que tenham indícios de participação da denunciada na imputação de ocultação de cadáver, não é o caso de ser processada pelo Tribunal do Júri, conforme ditames do art. $5^{\circ}$, inciso LIII, da Constituição Federal.

Posto isto, é o caso de impronúncia, absolvição sumária ou desclassificação (fl. 193 a 195 dos autos do processo).

Sua defesa alegou ainda que o Ministério Publico fez denúncia genérica "porque não descreveu a participação de cada acusado", sendo que "para que haja concurso é necessária a clara demonstração da unidade de desígnios na prática de qualquer infração, delito ou crime" e finaliza que "considerando a teoria da acessoriedade da participação, em relação à acusada, não é o caso nem de coautoria, nem de participação" (fl. 195 dos autos do processo).

Na audiência de instrução realizada em 22 de agosto de 2017, Anderson alegou legítima defesa e sua mulher, Talita, negou tenha atraído a vítima até sua casa.

Em resposta à acusação do Ministério Público, a defesa de Anderson, em Memorial (alegações finais), em 04 de setembro de 2017, postulou sua absolvição sumária e, alternativamente, a impronúncia.

O acusado ouvido em Juízo confessou em parte o delito, realmente da forma que ocorreu, a vítima foi encontrada com sua companheira na sua própria residência, deu-se início à uma discussão e em seguida luta corporal, ocasião em que a vítima se apossou de uma arma branca (faca), e na luta corporal o acusado foi mais feliz em se defender e aconteceu o ocorrido tudo por culpa da vítima que invadiu a residência do acusado para querer transar com sua esposa (fl. 359 a 361 dos autos do processo)

A defesa de Talita, no mesmo dia, nas suas alegações finais igualmente sustentou absolvição e, alternativamente, sua impronúncia, e para isso, conforme fl. 362 a 365 :

1. não é citação. É interpretação feita pelos autores.Retomou o depoimento do amigo e da mulher da vítima (que desconfiavam/sabiam de casos extraconjugais);

2. Argumentou sobre a existência de um telefone extra que a vítima tinha para falar com outras mulheres; 
3. Alegou o fato do irmão da vítima ter ficado surpreso ao descobrir que ele tinha salvado o endereço da casa da Talita como campo de futebol;

4. Retomou o depoimento da tia e do irmão da ré que moram no mesmo quintal e nunca presenciaram desentendimento entre o casal e que Anderson era tranquilo e trabalhador;

5. Afirmou que o trio amoroso começou bem antes quando eles trabalharam juntos num supermercado;

6. Argumentou que em nenhum momento Anderson se mostrou uma pessoa possessiva e ciumenta a ponto de chegar às vias de fato de um evento tenebroso como o que ocorreu;

7. Reiterou que este fator surpresa, de Anderson se transformar em possessivo e ciumento, espantou até mesmo a acusada, que a todo tempo ficou no outro cômodo da residência e sem ação nenhuma para evitar.

A defesa afirmou também que Anderson ficou transtornado e furioso ao surpreender Talita com a vítima:

Podia se absorver disto que no momento houve uma violenta emoção que fugiu ao perfil de Talita, o que também a fez com que ficasse por dias sem saber o que fazer diante do fato estarrecedor, se denunciava o acusado, ou fugia dele. É fato que o medo imperou na acusada, durante e nos instantes que se passaram. (fl. 364 dos autos do procesos).

Por seu turno, a defesa de Talita negou veementemente sua participação no homicídio:

Desta forma, em todos os depoimentos desde a fase inquisitorial, bem como durante a instrução judicial, não demonstraram a efetiva participação da acusada no crime imputado do evento morte; não houve uma prova sequer de que tenha a mesma concorrido, ou que tenha participado ou que tenha assumido o risco para o evento morte; o acusado Anderson, em depoimentos poucos divergentes, como bem afirmou o $\mathrm{MP}$, confessou a total autoria do crime. (fl. 365 dos autos do processo).

Em suma, a defesa de Anderson alegou legítima defesa e a de Talita negou sua participação no crime, imputando somente àquele (Anderson) a autoria do fato.

Após a explanação das teses esposadas pela defesa dos réus, passaremos à análise do que, em nossa opinião, teria faltado sustentar.

No decorrer da leitura do processo em tela, percebemos que não houve por parte da defesa nenhuma tentativa de argumentação em direção a convencer os julgadores de que as qualificadoras atribuídas aos acusados não se enquadrariam aos fatos narrados na denúncia.

Sobre a qualificadora do motivo torpe, prevista no inciso I do parágrafo $2^{\circ}$ art. 121 do Código Penal, há entendimento no Superior Tribunal de Justiça, em reiterados julgamentos, que o ciúme não configura motivo torpe, mesma posição encontrada em tribunais de justiça dos estados, é o que traz Rogério Greco em seu Código Penal Comentado: 
O sentimento de ciúme pode tanto inserir-se na qualificadora do inciso I ou II do parágrafo $2^{\circ}$, ou mesmo no privilégio do parágrafo primeiro, ambos do art. 121 do $\mathrm{CP}$, análise feita concretamente, caso a caso. 2. Conforme ressaltado pelo Tribunal de origem, "no caso em exame, imputou-se intrinsecamente ao réu que sua ação foi motivada por ciúme, cuja reação do sentimento humano não pode ser considerado motivo torpe e nem fútil" (e-STJ fl. 370). (STJ, Ag Rg no AREsp 363.919/PR, Rel. Ministro JORGE MUSSI, QUINTA TURMA, julgado em 13/05/2014, DJe 21/05/2014).

(...) bem como presentes os indicativos de autoria. Isso porque o réu assegurou ter desferido golpes de faca na vítima, fato confirmado. 2. Segundo a doutrina, torpe é o motivo baixo, repugnante, vil, ignóbil, que repugna a coletividade. O ciúme, por si só, não pode ser equiparado a motivo torpe 3. Há indicativos de que o acusado teria tentado ceifar a vida da vítima em razão do término do relacionamento amoroso. (TJRS, RESE, No 70052860954, Terceira Câmara Criminal, Tribunal de Justiça do RS, Relator: Nereu José Giacomolli, Julgado em: 28- 03-2013). (GRECO, 2016, p. 330).

Um dos argumentos da denúncia está embasado no fato de que Anderson, por ciúme de sua mulher, Talita, teria matado a vítima, razão porque a qualificadora poderia ter sido contestada e afastada.

Com relação à qualificadora do meio cruel contida no inciso III do parágrafo $2^{\circ}$ do mesmo art. 121, encontramos as seguintes decisões do Superior Tribunal de Justiça e de tribunais de justiça estaduais:

A só repetição de golpes de porrete contra a vítima não é circunstância capaz de autorizar a imposição da qualificadora do meio cruel, que só ocorre quando haja prova do meio bárbaro, martirizante, brutal, que aumenta, inutilmente, o sofrimento da vítima, revelando que a crueldade parte de um ânimo calmo, que permita a escolha dos meios capazes de infligir o maior padecimento desejado. Recurso a que se dá provimento parcial. (TJMG - RESE 1.0103.07.003039-2/001, Relator: Des. Judimar Biber, $1^{\text {a }}$ CÂMARA CRIMINAL, julgado em 11/12/2007, pub da súmula em 11/01/2008).

O meio cruel, previsto no art. 121, § 2o, III, do CP, é aquele em que o agente, ao praticar o delito, provoca um maior sofrimento à vítima. Vale dizer, quando se leva à efeito o crime com evidente instinto de maldade, objetivando impor à vítima um sofrimento desnecessário. Dessa maneira, a multiplicidade de atos executórios (in casu, reiteração de facadas), por si só, não configura a qualificadora do meio cruel (STJ, REsp. 743110/MG, Rel. Min. Felix Fischer, 5a T., DJ 27/3/2006 p. 322). (GRECO, 2016, p. 332,333).

Observamos, pois, que Anderson não teria imposto à vítima sofrimento de forma cruel e sua morte teria ocorrido quase instantaneamente com a perda de muito sangue ocasionada pelo ferimento profundo na jugular, conforme laudo do IML. (fl. 152 a 156 dos autos do processo). 
Na qualificadora do inciso IV do parágrafo $2^{\circ}$ do precitado art. 121 , utilização de recurso que dificultou ou tornou impossível a defesa do ofendido, segundo entendimento do Tribunal de Justiça do Rio Grande do Sul:

\begin{abstract}
O recurso que dificulta ou torna impossível a defesa do ofendido é aquele que se assemelha à traição, emboscada ou dissimulação. Não basta que a vítima não espere o ato agressivo, é necessário que se configurem hipóteses de surpresa para a vítima. Trata-se de fórmula genérica em que se exige que o recurso utilizado tenha a mesma natureza das qualificadoras da traição, emboscada e dissimulação (fórmulas estas casuísticas). Essa qualificadora traduz um modo insidioso da atividade executiva do crime, que obsta a defesa da vítima, comprometendo total ou parcialmente seu potencial defensivo (TJRS, RSE 70035215474, 3a Câmara Criminal, Rel. Des. Odone Sanguiné, DJERS 30/7/2010), (GRECO, 2016, p. 333).
\end{abstract}

Também não vimos presente essa qualificadora nos fatos, pois, conforme descrito nos depoimentos, a vítima e Anderson entraram em luta corporal e, conforme histórico de constituição física, a vítima seria mais alta que seu algoz e possuía porte atlético, ou seja, não teve sua defesa dificultada e poderia ter se defendido, malgrado ter sido atingido mortalmente.

Como estudantes de Direito fomos incentivados a olhar o processo e tecer críticas ou outras hipóteses poderiam servir de argumento às defesas de Anderson e Talita, a saber:

1. Não houve menção no decorrer do processo ao contexto histórico, sócial e econômico dos envolvidos. Sabemos que os indivíduos influenciam e são influenciados diretamente pelo ambiente em que vivem e desenvolvem suas relações sociais e afetivas.

2. A acusação alegou que Anderson amarrou e estrangulou a vítima com um fio, no entanto o laudo pericial necroscópico não faz menção a marcas de estrangulamento e nem de amarras e afirma que a causa mortis decorreu de 4 cortes (sendo 3 superficiais e um profundo) no pescoço.

3. Se a acusação optou pela tese de que Talita agiu com dolo eventual, como fica o concurso de agentes? A defesa de Talita poderia ter aproveitado mais essa questão;

4. Se o crime foi cometido pelo motivo de a vítima estar se relacionando sexualmente com sua mulher, por qual motivo Anderson não mutilou o órgão sexual da vítima? Por que Anderson não matou Talita? São questionamentos que poderiam ter sido levantados pela defesa em prol do acusado.

5. Questão do porte físico do ofendido: era mais alto e atlético $(1,80 \mathrm{~m}$ contra $1,70 \mathrm{~m})$. A Defesa poderia ter suscitado que na ocorrência de luta corporal que Anderson levou a melhor por questão de sorte, já que a vítima era maior e mais forte do que ele; 
6. Talita faz menção em seu interrogatório que já praticara sexo com dois parceiros, sendo um deles o seu marido Anderson (mas não cita quem seria o/a terceiro/a).

7. Considerando a hipótese levantada acima, seria possível à Talita prever o resultado de seu ato em tentar promover relação sexual com dois parceiros? Anderson teria matado o amante da mulher para puni-la e fazê-la sentir-se culpada? A defesa de Talita poderia ter enfatizado mais a liberdade sexual da ré e da própria sociedade no século XXI;

8. A defesa poderia atentar mais sobre a questão da exposição midiática na televisão e redes sociais, que provocam e manipulam a opinião pública e levam a certo prejulgamento em favor da acusação.

Em suma, os três protagonistas desse triste episódio são originários de famílias identicamente desestruturadas, possuem perfis psicológicos bem parecidos, levianos, vulgares e inconsequentes. Assim como a vítima morreu, poderiam ter morrido Anderson e/ou Talita.

Por isso, quando escola, família, religião, moral e ética revelam-se ausentes há personalidades malformadas e esse pode ter sido o real motivo do crime de homicídio.

A nosso ver, todos os três são vítimas do modelo social (desigual) atual da periferia das grandes cidades. Três jovens saudáveis fisicamente, mas doentes nas suas personalidades, emocional e psicologicamente doentes!

\section{CONCLUSÕES}

Sabemos que o homicídio é dos crimes mais impactantes de uma sociedade, consistente na eliminação da vida humana por outrem.

No caso em exame, segundo as provas coligidas ao processo, o homicídio foi praticado por motivo torpe e com a utilização de meio que impossibilitou a defesa da vítima. Ao que consta, dois foram os seus autores, um homem e uma mulher, os quais, na sequência, teriam ido ao cinema e depois a um motel e, no dia seguinte, ocultaram o cadáver da vítima em local distante, sendo descoberto apenas 11 dias depois, em 13/3/2017, já em estado de putrefação.

Outra abordagem necessária relacionou-se a imprescindível colaboração do irmão da vítima, que não sossegou enquanto a Polícia Civil não elucidou amiúde o crime e prendeu seus autores.

O Grupo de Estudos se utilizou de reportagens jornalísticas sobre o caso, vários documentos constantes dos autos da ação penal e obras científicas de Criminologia, Direito Penal e Direito Processual Penal e teve por objetivos analisar o crime conhecido como Caso Talita, suas causas e consequências e, especificamente, apresentar os fatos segundo a visão jornalística e popular. Objetivou também analisar suas causas e consequências, estudar as teses da acusação e defesa e correlatas várias decisões judiciais. Buscou, assim, demonstrar a importância do debate acadêmico sobre fatos da vida real, com a participação direta dos alunos em interação com profissionais experimentados. 


\section{REFERENCIAS}

ARAÚJO, Sebastião Simões de. Análise crítica do tribunal do júri em face da soberania, na publicidade e oralidade. Disponível em: <http://dominiopublico.mec.gov.br/download/teste/arqs/cp077108.pdf>. Acesso em: 31 mai 2020.

BASTOS, Celso Ribeiro; MARTINS, Ives Gandra. Comentários a constituição do Brasil: promulgada em 5 de outubro de 1988. São Paulo: Saraiva, 2000

BISINOTTO, Edneia Freitas Gomes. Origem, história, principiologia e competência do tribunal do júri. Disponível em: Disponível em < https://ambitojuridico.com.br/edicoes/revista-86/origem-historia-principiologia-e-competencia-do-tribunal-do-juri_> Acesso em 21 jun 2020.

BRASIL. Lei n. 2.848, de 7 de dezembro de 1940. Institui o Código Penal. Disponível em: <http://www.planalto.gov.br/ccivil_03/decreto-lei/del2848compilado.htm>. Acesso em: 08 jun 2020.

BRASIL. Lei n. 3.689, de 3 de outubro de 1941. Institui o Código de Processo Penal. Disponível em: <http://www.planalto.gov.br/ccivil_03/decreto-lei/del3689.htm>. Acesso em $08 / 06 / 2020$.

Código de Processo Penal. Decreto-lei 3.689, de 3 de outubro de 1941. Vade Mecum Saraiva. São Paulo: Saraiva, 2017.

Constituição da república federativa do Brasil de 1967.

. Constituição da república federativa do Brasil de 1988.

. Constituição dos estados unidos do Brasil de 1946.

. Constituição política do império do Brazil de 1824.

Lei de 29 de novembro de 1832. Promulga o Código do Processo Criminal de primeira instancia com disposição provisória acerca da administração da justiça civil. Disponível em: <http://www.planalto.gov.br/ccivil_03/leis/lim/LIM-29-11-1832.htm>. Acesso em: 21 jun 2020.

BUTLER, Judith. Quadros de guerra: Quando a vida é passível de luto? / Judith Butler; Rio de Janeiro: Civilização Brasileira, 2015.

CLEMENT, Elizabeth. et. al. Dicionário prático de filosofia. Lisboa, Portugal, 1997. CONSELHO NACIONAL DE JUSTIÇA. CNJ Serviço. Você conhece a lei do feminicídio? Disponível em: <https:/ / www.cnj.jus.br/cnj-servico-voce-conhece-a-lei-do-feminicidio/>. Acesso em 06 jun 2020.

CONSELHO NACIONAL DE JUSTIÇA: Lei maria da penha. Disponível em: <https://www.cnj.jus.br/lei-maria-da-penha>. Acesso em 6 jun 2020.

FONTES, Renato. Jovem desaparecido é encontrado morto em São Bernardo. Disponível em <http:/ / renatofontes.com/?p=2218>. Acesso em: 08 jun. 2020. 
GRECO, Rogério. Código penal comentado / Rogerio Greco. 10ª ed. Niterói: Impetus, 2016.

HUNGRIA, Nelson. Comentários ao código penal. Vol. V. Artigos 121 a 136. Belo Horizonte: Forense, 1979.

LIMA, Renato Brasileiro de. Manual de processo penal. $8^{a}$ ed. Salvador: JusPodivm. 2020. MARCÃO, Renato. Recebimento da denúncia ou queixa: os arts. 396, caput, e 399, do CPP. Disponível em: <https://www.migalhas.com.br/depeso/73990/recebimento-da-denuncia-ou-queixa-os-arts-396-caput-e-399-do-cpp>. Acesso em 21 jun 2020.

MINISTÉRIO PÚBLICO DO CEARÁ. A influência da mídia nos processos judiciais criminais. Disponível em: <http://www.mpce.mp.br/wp-content/uploads/2019/12/ARTIGO-1.pdf. Acesso em: 31 mai 2020.

MORAES, Alexandre de. Direito constitucional. 33a ed. São Paulo: Atlas, 2017.

MOSSIN, Heráclito Antônio. Júri: crimes e processo. São Paulo: Atlas, 1999.

NUCCI, Guilherme de Souza. Código de Processo Penal Comentado. 10a ed. São Paulo: Revista dos Tribunais, 2011.

PRADO, Luiz Regis. Curso de Direito Penal Brasileiro. São Paulo: Revista dos Tribunais, 2008.

RECORD TV. Cidade Alerta. Mulher retoma o relacionamento com o marido e os dois matam o ex-amante. Disponível em <https:/ / recordtv.r7.com/cidade-alerta/videos/mulher-retoma-o-relacionamento-com-o-marido-e-os-dois-matam-o-ex-amante-20102018>. Acesso em: 08 jun 2020.

ROMANO, Rogério Tadeu. Do júri popular. Disponível em: <https://www.jfrn.jus.br/ institucional/biblioteca-old/doutrina/Doutrina255_DoJuriPopular.pdf>. Acesso em: 31 mai 2020.

SÃO PAULO. Secretaria de Segurança Pública. Disponível em <https:/ / www.ssp.sp.gov. br/Estatistica/PerfilHomicidio.aspx>. Acesso em: 02 jun 2020.

SÃO PAULO. Secretaria de Segurança Pública. Disponível em <https:/ / www.ssp.sp.gov. br/Estatistica/Pesquisa.aspx>. Acesso em: 03 jun 2020.

SILVA, De Plácido e. Vocabulário jurídico. Atualizadores: Nagib Slaibi Filho e Priscila Pereira Vasques Gomes. 31 ${ }^{\mathrm{a}}$ ed. Rio de Janeiro: Forense, 2014.

SUPERIOR TRIBUNAL DE JUSTIÇA. AGRAVO REGIMENTAL NO RECURSO ESPECIAL: REsp 1636954/CE, Relator: Ministro JORGE MUSSI, QUINTA TURMA, julgado em 17/08/2017, DJe 23/08/2017. Disponível em: <https://scon.stj.jus.br/SCON/jurisprudencia/doc.jsp>. Acesso em 08 jun 2020.

TRIBUNAL DE JUSTIÇA DE SÃO PAULO. Processo: 0005959-16.2017.8.26.0564. Disponível em: < https:/ /esaj.tjsp.jus.br >. Acesso em: 21 jun 2020.

TUCCI, Rogério Lauria. Direitos e garantias individuais no processo penal brasileiro. São Paulo: Saraiva, 1993. 